\title{
PERSEPSI PESERTA DIKLAT PENILAIAN PEMBELAJARAN TERHADAP PEMANFAATAN APLIKASI CLASS123 UNTUK PENILAIAN SIKAP
}

\author{
Ratna Prilianti \\ Balai Diklat Keagamaan Semarang \\ ratna.prilianti@gmail.com
}

DOI: http://doi.org/10.37730/edutrained.v4i1.59

Diterima: 19 Maret 2020 | Disetujui: 14 April 2020 | Dipublikasikan: 6 Juli 2020

\begin{abstract}
Abstrak
Tujuan penelitian ini untuk mengukur persepsi peserta diklat terhadap kemudahan dan kebermanfaatan penggunaan Class123 iuntuk penilaian sikap. Penelitian ini merupakan penelitian deskriptif dengan metode survei. Instrumen penelitian berupa kuesioner yang diberikan secara langsung. Penelitian ini dilaksanakan di Balai Pendidikan dan Pelatihan Keagamaan Semarang pada Diklat Teknis Substantif Penilaian Pembelajaran. Jumlah peserta diklat sebanyak tiga puluh lima orang guru yang mendeskripsikan persepsi mereka tentang pemanfaatan aplikasi Class123 untuk menilai sikap. Hasil dan simpulan penelitian menunjukkan persepsi peserta diklat terhadap kemudahan penggunaan Class123 di mana dalam rentang 51,43\% - 62,86\% orang responden menyatakan sangat setuju pada butir angket 1 yaitu menggunakan Class 123 untuk penilaian sikap sangat jelas dan mudah dipahami dan butir angket ke-3, yaitu menggunakan Class123 untuk penilaian sikap sangat mudah dalam penggunaanya. Persepsi peserta diklat terhadap manfaat Aplikasi Class123 menunjukkan hasil responden menyatakan sangat setuju sebanyak 60\%-91,43\% responden pada butir angket pernyataan ke-8 yaitu Class123 efektif digunakan untuk penilaian sikap dan pernyataan ke-5 yaitu menggunakan Class123 dapat bekerja lebih cepat. Saran yang diajukan adalah perlu dilakukan penelitian lanjutan untuk mengetahui persepsi kenyamanan pengguna aplikasi Class123. Selain itu, perlunya pendampingan kepada guru-guru di madrasah masing-masing ketika menggunakan Class123 dalam menilai sikap, sehingga diharapkan hasilnya lebih maksimal.
\end{abstract}

Kata Kunci: persepsi, Class123, penilaian sikap

\begin{abstract}
The purpose of this study was to measure training participants' perceptions of the ease and usefulness of using Class123 for attitude assessment. This research was a descriptive study with a survey method. The research instrument was in the form of a questionnaire given directly. This research was conducted at the Semarang Religious Education and Training Office in the Substantive Technical Education Learning Assessment. The number of training participants was thirty-five teachers who described their perceptions about the use of the Class123 application to assess attitudes. The results and conclusions of the study indicate the training participants perceptions of the ease of use of Class 123 where in the range of $51.43 \%$ - 62.86\% of the respondents stated strongly agree on item 1 questionnaire namely Using Class123 for the assessment of attitudes very clear and easily understood and item 3 questionnaire, that is, using Class 123 for attitude assessment is very easy to use. Training participants' perception of the benefits of the Class123 Application showed the results of the respondents stated strongly agree as much as $60 \%-91.43 \%$ of respondents in the 8th statement item questionnaire that Class123 was effective for attitude assessment and the 5th statement using Class123 showed ean work faster. Suggestions proposed are that further research needs to be done to determine the comfort perception of Class123 application users. In addition, the need for mentoring to teachers in their respective madrasas when using Class123 in assessing attitudes, so that the expected results are more optimal.
\end{abstract}

Keywords: perception, Class123, attitude assessment 



\section{PENDAHULUAN}

Keberhasilan pendidikan banyak ditentukan oleh kemampuan guru dalam melaksanakan tugasnya (Ardi, 2017). Guru sebagai komponen penting pada pendidikan di sekolah memiliki 5 tugas pokok seperti: (1) menganalisis isi kurikulum, salah satunya menyusun perencanaan pembelajaran seperti menyusun program tahunan, program semesteran, program mingguan sampai ke program harian; (2) melaksanakan pembelajaran, yaitu tugas guru pada saat menyampaikan tujuan dan materi pembelajaran, dengan memilih metode, penggunaan alat/media dalam pembelajaran; (3) melaksanakan evaluasi/penilaian; (4) melaksanakan tugas dengan rasa tanggung jawab. (Muhani, Imron, \& Kusmintardjo, 2016).

Guru melaksanakan penilaian proses dan hasil belajar secara berkesinambungan. Guru melakukan evaluasi atas efektivitas proses dan hasil belajar dan menggunakan informasi hasil penilaian dan evaluasi untuk merancang program remedial dan pengayaan. Guru menggunakan hasil analisis penilaian dalam proses pembelajarannya (Nur, 2014). Penilaian pembelajaran dilakukan oleh guru kelas dan guru mata pelajaran secara langsung, ditambah dengan Guru BK pada MTs dan MA. Aspek penilaian dalam kurikulum 2013 adalah aspek penilaian sikap, pengetahun dan keterampilan yang tercantum dalam Permendikbud (Permendikbud RI No. 20, 2016). Penilaian sikap bertujuan untuk mengevaluasi perilaku peserta didik dalam proses pembelajaran yang meliputi sikap spiritual dan sosial. Karakteristik penilaian sikap berbeda dari penilaian pengetahuan dan keterampilan sehingga teknik penilaian yang digunakan juga berbeda. Penilaian sikap lebih ditujukan untuk membina perilaku dalam rangka pembentukan karakter peserta didik. Penilaian sikap terdiri atas penilaian utama dan penilaian penunjang. Penilaian utama diperoleh dari hasil observasi harian yang ditulis di dalam jurnal harian. Penilaian penunjang diperoleh dari penilaian diri dan penilaian antarteman, hasilnya dapat dijadikan sebagai alat konfirmasi dari hasil penilaian sikap oleh pendidik.

Kompetensi inti (KI) yang tertuang dalam Permendikbud Nomor 37 tahun 2018 menunjukkan adanya tuntutan penilaian sikap spiritual dan sosial. Pada mata pelajaran selain Pendidikan Agama dan PKn tidak terdapat Kompetensi dasar yang berasal dari KI 1 (sikap spiritual) dan KI 2 (sikap sosial). Meskipun demikian penilaian sikap spiritual dan sikap sosial harus dilakukan secara berkelanjutan oleh semua guru mata pelajaran dan wali kelas, melalui observasi dan informasi lain yang valid dan relevan.

Hasil wawancara penulis dengan guru-guru madrasah yang sedang mengikuti diklat penilaian pembelajaran di Balai Diklat Keagamaan Semarang menunjukkan hasil sebagian besar memiliki format jurnal perkembangan peserta didik di madrasahnya. Namun, format tersebut keseluruhan tidak diisi dengan sikap siswa yang menonjol positif atau negatif, atau dapat dikatakan blanko tersebut hanya sebatas untuk pemenuhan kebutuhan administrasi. Hal ini disebabkan karena melakukan penilaian sikap adalah sesuatu yang merepotkan dan menghabiskan waktu. Penilaian aspek sikap diperlukan dalam proses pembelajaran. Allen \& Friedman (2010) menyatakan bahwa yang paling kompleks dalam pembelajaran adalah integrasi pembelajaran berbagai domain yaitu kognitif, perilaku, dan perasaan. Menurut Retnawati (2015: 398-400) salah satu aspek yang menjadi hambatan implementasi kurikulum 2013 adalah sistem penilaian yang rumit dan perlu waktu yang lama untuk menyusun laporan penilaian. Teknik penilaian capaian pengetahuan dan keterampilan relatif tidak menjadi kendala. Hal yang benar-benar baru adalah penilaian sikap, di mana penilaian tersebutlah yang mayoritas dikeluhkan oleh guru karena 
dianggap menyulitkan. Retnawati (2015: 400) menyatakan bahwa salah satu hambatan terbesar dalam penilaian adalah penilaian sikap. Wawasan guru dalam memilih metode yang tepat dan mengembangkan instrumen penilaian tersebut masih kurang. Mengingat pentingnya keterlaksanaan penilaian yang baik dalam mendukung keterlaksanaan kurikulum maka perlu ada kajian mengenai bagaimana implementasi penilaian sikap pada Kurikulum 2013 di madrasah.

Penggunaan aplikasi penilaian diperlukan untuk membantu para guru melakukan penilaian khususnya aspek penilaian sikap. Salah satu aplikasi yang bisa digunakan untuk menilai sikap peserta didik adalah dengan aplikasi Class123. Class123 adalah aplikasi manajemen kelas dengan berbagai alat dan fitur komunikasi online yang membantu meningkatkan perilaku siswa dengan memberikan umpan balik berupa kartu maupun poin. Class123 pada dasarnya adalah aplikasi sederhana yang dapat digunakan untuk mengukur interaksi yang terjadi di kelas. Program Class123 ini karena memiliki banyak fitur yang telah terbukti sangat bermanfaat bagi guru yang mempunyai banyak kesibukan.

Balai Pendidikan dan Pelatihan Keagamaan merupakan salah satu lembaga pendidikan informal yang mendidik, melatih dan membimbing para guru agar dapat meningkatkan kompetensinya terutama kompetensi profesional dan kompetensi pedagogik. Salah satu jenis diklat yang dilakukan oleh balai diklat adalah melaksanakan Diklat Reguler, salah satunya Diklat Teknis Substantif Penilaian Pembelajaran bagi Guru Madrasah se Jawa Tengah dan D.I. Yogyakarta yang dilaksanakan di Balai Diklat Keagamaan Semarang.

Melakukan kegiatan penilaian terhadap proses pembelajaran di kelas, khususnya penilaian aspek sikap dengan menggunakan teknik yang sesuai diharapkan dapat meningkatkan kompetensi pedagogik para guru madrasah. Hal yang harus dipersiapkan guru untuk melakukan proses penilaian sikap adalah memuat instrumen penilaian, merekap, mengolah dan melaporkan penilaian sikap. Melihat urgensitas penilaian sikap yang harus dilakukan oleh seorang guru, maka aspek penilaian sikap menjadi salah satu mata diklat inti pada Diklat Teknis Substantif Penilaian Pembelajaran.

Berdasarkan hasil wawancara penulis dengan guru-guru madrasah yang sedang mengikuti diklat penilaian pembelajaran di Balai Diklat Keagamaan Semarang menunjukkan hasil sebagian besar belum melakukan penilaian sikap secara berkelanjutan. Untuk memudahkan para guru melakukan penilaian sikap maka penulis memberikan gagasan kepada peserta diklat untuk menggunakan sebuah aplikasi. Aplikasi yang dipraktikkan dalam diklat penilaian pembelajaran mata diklat aspek penilaian sikap adalah menggunakan Class123. Pemanfaatan aplikasi Class123 ini diharapkan dapat memberikan manfaat kepada peserta diklat. Oleh karena itu perlu dilakukan pengukuran persepsi untuk mengevaluasi kebermanfaatan dan kemudahan penggunaan Class123 ini untuk penilaian sikap.

Tujuan penelitian ini adalah untuk mengetahui persepsi peserta diklat terhadap kemudahan dan manfaat penggunaan Aplikasi class123 dalam penilaian sikap.

\section{KAJIAN PUSTAKA}

\section{A. Persepsi}

Persepsi adalah sebuah proses individu mengorganisasikan dan menintepretasikan kesan sensoris pada lingkungannya. Apa yang kita nilai bisa jadi berbeda secara substansial dengan realitas objektif (Robbins \& Judge, 2008:103). Persepsi penting bagi perilaku organisasi karena perilaku orang-orang berdasarkan pada persepsi mereka tentang apa realita yang ada, bukan mengenai realita itu sendiri (Robbins \& Judge, 2008:103). Menurut (Salim \& Kleiner, 2001) bahwa persepsi adalah: 1) Pandangan dari seseorang atau 
banyak orang akan suatu hal atau peristiwa yang didapat atau dialaminya, dan 2) Proses diketahuinya suatu hal pada sesorang melalui panca indera yang dimilikinya.

Sementara itu, menurut Kwich dalam Notoatmodjo (2007:72) menyatakan bahwa Perubahan-perubahan perilaku dalam diri seseorang dapat dikemukakan melalui persepsi. Dari pendapat para pakar tersebut dapat disimpulkan bahwa persepsi merupakan pandangan dari sesorang tentang suatu hal melalui panca indera kemudian mengartikannya.

\section{B. Penilaian Autentik}

Penilaian merupakan bagian integral dari proses pembelajaran (Ani, 2013). Penilaian merupakan salah satu dari tiga pilar utama yang sangat menentukan kegiatan pembelajaran. Ketiga pilar tersebut adalah perencanaan, pelaksanaan dan penilaian. Apabila ketiga pilar tersebut sinergis dan berkesinambungan, maka akan sangat menentukan kualitas pembelajaran. Oleh karena itu penilaian harus dirancang dan dilaksanakan sesuai dengan perencanaan dan pelaksanaan pembelajaran. Sistem Penilaian dalam kurikulum 2013 tidak hanya mengedepankan aspek kognitif saja, namun didesain dengan menggunakan penilaian autentik. Penilaian autentik merupakan penilaian untuk mengukur secara keseluruhan hasil dan proses belajar dengan berbagai cara. Penilaian autentik merupakan penilaian yang bermakna atas hasil belajar siswa untuk ranah sikap, pengetahuan, dan keterampilan (Arifiian, Dus, n.d.: 2014:135 ).

\section{Aspek Penilaian Sikap}

Penilaian sikap adalah penilaian terhadap kecenderungan perilaku peserta didik sebagai hasil pendidikan, baik di dalam kelas maupun diluar kelas (Kementerian, 2015). Penilaian sikap memiliki karakteristik yang berbeda dengan penilaian pengetahuan dan keterampilan, sehingga teknik penilaian yang digunakan juga berbeda. Dalam hal ini, penilaian sikap ditujukan untuk mengetahui capaian dan membina perilaku serta budi pekerti peserta didik. Pada mata pelajaran Pendidikan Agama Islam dan mata pelajaran Pendidikan Pancasila dan Kewarganegaraan (PKn), KD pada KI-1 dan KD pada KI-2 disusun secara koheren dan linier dengan $\mathrm{KD}$ pada KI-3 dan KD pada KI-4. Dengan demikian, aspek sikap untuk mata pelajaran Pendidikan Agama Islam dan PPKn dibelajarkan secara langsung (direct teaching) maupun tidak langsung (indirect teaching) yang memiliki dampak instruksional (instructional effect) dan memiliki dampak pengiring (nurturant effect). Sedangkan untuk mata pelajaran lain, tidak terdapat KD pada KI-1 dan KI-2 (kementerian, 2015). Dengan demikian aspek sikap untuk mata pelajaran selain Pendidikan Agama Islam dan PPKn tidak dibelajarkan secara langsung dan memiliki dampak pengiring dari pembelajaran KD pada KI-3 dan KD pada $\mathrm{KI}-4$.

Instrumen penilaian aspek sikap adalah lembar observasi, lembar penilaian diri dan lembar penilaian antar teman. Penilaian sikap diasumsikan bahwa setiap peserta didik memiliki perilaku yang baik. Perilaku menonjol (sangat baik atau perlu bimbingan) yang dijumpai selama proses pembelajaran ditulis dalam jurnal atau catatan pendidik. Apabila tidak ada catatan perlu bimbingan di dalam jurnal, peserta didik tersebut dikategorikan berperilaku sangat baik. Hasil observasi yang dilakukan oleh penulis dan hasil wawancara penulis dengan para guru madrasah sebagian besar guru madrasah tidak pernah mengisi jurnal perkembangan peserta didik dengan alasan terlalu banyak pekerjaan lain yang harus diselesaikan oleh guru dan tidak tersedianya waktu untuk menuliskan hasil observasi ke dalam jurnal.

\section{Aplikasi Class123}

Aplikasi adalah suatu program siap pakai yang dapat digunakan untuk menjalankan perintah dari pengguna aplikasi dengan tujuan mendapatkan hasil yang lebih akurat sesuai dengan 
tujuan pembuatan aplikasi tersebut(Priana \& Fitriani, 2017:408).

Aplikasi yang digunakan dalam penelitian ini adalah aplikasi Class123. Aplikasi ini dikembangkan oleh Bravepops Company pada tahun 2013. Class123 adalah aplikasi manajemen kelas dengan berbagai alat dan fitur komunikasi online yang membantu meningkatkan perilaku siswa dengan memberikan umpan balik berupa kartu maupun poin (Kaensige \& Yohansa, 2018). Tahapan aplikasi Class123 ini diambil berdasarkan langkah-langkah penggunaannya yaitu sebagai berikut:

1. Mendaftar di http://Class123.ac dari PC Anda atau unduh aplikasi seluler

2. Buat kelas, Klik 'Tambah kelas' di daftar. Pilih jenis avatar dan masukkan nama siswa.

3. Kelola kartu, Tambahkan kartu Wow atau No-no Anda sendiri.

4. Tetapkan visibilitas titik, Pilih apa yang akan dibagikan dengan orang tua dan siswa.

5. Unggah foto siswa, Mudah mengingat nama siswa dengan foto asli.

6. Mengakumulasikan setiap poin yang diperoleh siswa di setiap akhir pertemuan

Aplikasi clas123 sebagai aplikasi yang dapat merekam aktivitas sikap dan perilaku peserta didik dengan melalui serangkaian umpan balik berupa kartu dan reward berupa poin. Kartunya berupa wow wow card untuk rekaman sikap yang positif dan no no card untuk sikap yang negatif.

E. Diklat Penilaian Pembelajaran

Balai Pendidikan dan Pelatihan Keagamaan merupakan salah satu lembaga pendidikan informal yang mendidik, melatih dan membimbing para guru agar dapat meningkatkan kompetensinya terutama kompetensi profesional dan kompetensi pedagogik (Prilianti, 2017:32). Salah satu jenis diklat yang dilakukan oleh balai diklat adalah melaksanakan Diklat Reguler, salah satunya Diklat Teknis Substantif (DTS) Penilaian Pembelajaran bagi Guru Madrasah se Jawa Tengah dan D.I.
Yogyakarta yang dilaksanakan di Balai Diklat Keagamaan Semarang. Struktur kurikulum mata diklat inti untuk DTS penilaian pembelajaran adalah : Konsep penilaian, pemetaan pembelajaran, penialain sikap, penilaian pengetahuan, penilaian ketrampilan dan analisis butir sikap.

Salah satu jenis diklat reguler yang dilaksanakan tahun 2019 oleh Balai Pendidikan dan Pelatihan Keagamaan Semarang adalah DTS Penilaian Pembelajaran bagi Guru Madrasah. DTS penilaian pembelajaran dilaksanakan di BDK Semarang tanggal 26 s.d. 31 Agustus 2019. Peserta DTS Penilaian Pembelajaran adalah 35 Guru MI/MTs/MA se Provinsi Jawa Tengah dan D.I. Yogyakarta

F. Penelitian yang Relevan

Hasil penelitian Hidayat \& Nugrahanti (2018) menunjukkan bahwa hasil penilaian dengan menggunakan aplikasi otomatisasi penilaian sikap siswa yang dibuat, sudah dapat menggantikan model penilaian yang dijalankan secara manual selama ini, karena model penilaian manual tidak dapat berjalan secara cepat, efektif dan efisien.

Hasil akhir penelitian (Warsiyo, 2018) diperoleh sebuah aplikasi sistem pencapaian kompetensi yang memiliki kemampuan dan mengolah penilaian peserta didik, serta sistem ini memproses pencetakan hasil akhir laporan capaian kompetensi peserta didik (rapor). Berdasarkan hasil pengujian terhadap pengguna (guru mata pelajaran, wali kelas dan tim kurikulum), secara umum sistem ini sangat membantu pihak-pihak terkait dalam mengelola data penilaian peserta didik secara mudah dan efektif.

Penelitian yang dilakukan ini berbeda dengan kedua penelitian di atas dalam hal aplikasi yang digunakan yaitu dengan menggunakan aplikasi class123.

\section{METODE PENELITIAN}

\section{Metode Penelitian}

Penelitian ini merupakan penelitan deskriptif dengan metode survei. 
Kerlinger dalam Sugiono (2001: 79) mengemukakan bahwa:

Penelitian survei adalah penelitian yang dilakukan pada populasi yang besar maupun kecil, tetapi yang dipelajari adalah data dari sampel yang diambil dari populasi tersebut, sehingga ditemukan kejadian relatif, distribusi dan hubungan antar variabel. bahwa:

Nasir (1988: 138) mengemukakan

Metode survei adalah penyelidikan yang diadakan untuk memperoleh fakta-fakta dari gejala yang ada dan mencari keterangan secara faktual baik tentang institusi pendidikan, sosial, ekonomi atau politik dari suatu kelompok, ataupun suatu daerah.

\section{Populasi dan Sampel}

Penelitian ini dilaksanakan di Balai Pendidikan dan Pelatihan Keagamaan Semarang khususnya pada kegiatan Diklat Teknis Fungsional Penilaian Pembelajaran yang dilaksanakan selama 6 hari. Peserta diklat adalah para guru madrasah di lingkungan kerja Balai Diklat Keagamaan Semarang yaitu Kantor Wilayah Kementerian Agama Provinsi Jawa Tengah.dan Provinsi D.I. Yogyakarta.

Populasi dan sampel penelitian ini adalah peserta diklat sebanyak 35 orang guru peserta DTS penilaian pembelajaran.

\section{Instrumen Penelitian}

Instrumen penelitian adalah kuesioner yang memuat variabel kemudahan dan kebermanfaatan penggunaan aplikasi class123. Kemudahan penggunaan adalah: 1) user percaya bahwa teknologi/ sistem tersebut dapat digunakan dengan mudah; 2) user percaya bahwa teknologi/ sistem tersebut bebas dari masalah, 3) intensitas penggunaan, dan 4)interaksi antara pengguna dengan sistem. Sedangkan pada aspek manfaat adalah : 1)bekerja lebih cepat, 2) prestasi kerja, 3) meningkatkan produktivitas, 4) efektivitas, 5) mempermudah pekerjaan, dan 6) berguna.

Instrumen ini bertujuan untuk mendeskripsikan persepsi mereka tentang pemanfaatan aplikasi Class123 untuk menilai sikap peserta didik dengan mengkaji dokumen yang ada dari kegiatan evaluasi pada mata diklat penilaian sikap

\section{HASIL PENELITIAN DAN PEMBAHASAN}

\section{Hasil Penelitian}

\section{a. Persepsi Peserta terhadap} kemudahan Penggunaan Class123

Aspek kemudahan penggunaan Class123 dalam penilaian sikap terdiri dari penggunaan yang jelas dan mudah dipahami, tidak terlalu menyita waktu, sangat mudah dalam penggunannya dan membantu proses evaluasi. Hasil penelitian tentang persepsi peserta diklat penilaian pembelajaran terhadap kemudahan penggunaan aplikasi Class123 adalah seperti pada tabel berikut ini.

Tabel 1. Kemudahan Penggunaan

\begin{tabular}{|c|c|c|c|c|c|}
\hline \multirow[t]{2}{*}{ No } & \multirow[t]{2}{*}{ Butir Pertanyaan } & \multicolumn{4}{|c|}{ Jawaban } \\
\hline & & STS & TS & $\mathrm{S}$ & SS \\
\hline 1 & $\begin{array}{l}\text { Menggunakan } \\
\text { Class123 untuk } \\
\text { penilaian sikap } \\
\text { sangat jelas dan } \\
\text { mudah dipahami }\end{array}$ & - & 2 & 15 & 18 \\
\hline 2 & $\begin{array}{l}\text { Menggunakan } \\
\text { Class123 untuk } \\
\text { penilaian sikap } \\
\text { tidak terlalu banyak } \\
\text { menyita waktu guru }\end{array}$ & - & 2 & 13 & 20 \\
\hline 3 & $\begin{array}{l}\text { Menggunakan } \\
\text { Class } 123 \text { untuk } \\
\text { penilaian sikap } \\
\text { sangat mudah } \\
\text { dalam } \\
\text { penggunaanya }\end{array}$ & - & - & 13 & 22 \\
\hline 4 & $\begin{array}{l}\text { Menggunakan } \\
\text { Class123 untuk } \\
\text { penilaian sikap } \\
\text { sangat membantu } \\
\text { dalam proses } \\
\text { evaluasi }\end{array}$ & - & - & 16 & 19 \\
\hline
\end{tabular}




\section{b. Persepsi Peserta terhadap Manfaat Class123}

Aspek manfaat aplikasi Class123 dalam penilaian sikap terdiri dari dari dapat bekerja lebih cepat, dapat meningkatkan kompetensi pedagogik, dapat meningkatkan produktivitas, digunakan untuk penilaian sikap, mempermudah pekerjaan dalam melakukan penilaian sikap, bermanfaat bagi guru dalam menilai sikap. Hasil penelitian tentang persepsi peserta diklat penilaian pembelajaran terhadap manfaat aplikasi Class123 dalam penilaian sikap adalah sebagai berikut.

Tabel 2. Tabel persepsi peserta

\begin{tabular}{|c|c|c|c|c|c|}
\hline \multirow[t]{2}{*}{ No } & \multirow{2}{*}{$\begin{array}{c}\text { Butir } \\
\text { Pertanyaan }\end{array}$} & \multicolumn{4}{|c|}{ Jawaban } \\
\hline & & STS & TS & $S$ & SS \\
\hline 1 & $\begin{array}{l}\text { Menggunakan } \\
\text { Class } 123 \\
\text { dapat bekerja } \\
\text { lebih cepat }\end{array}$ & - & - & 3 & 32 \\
\hline 2 & $\begin{array}{l}\text { Menggunakan } \\
\text { Class } 123 \\
\text { dapat } \\
\text { meningkatkan } \\
\text { kompetensi } \\
\text { pedagogik }\end{array}$ & - & - & 10 & 25 \\
\hline 3 & $\begin{array}{l}\text { Menggunakan } \\
\text { Class } 123 \\
\text { dapat } \\
\text { meningkatkan } \\
\text { produktivitas }\end{array}$ & - & - & 7 & 28 \\
\hline 4 & $\begin{array}{l}\text { Class } 123 \\
\text { efektif } \\
\text { digunakan } \\
\text { untuk } \\
\text { penilaian } \\
\text { sikap }\end{array}$ & - & - & 14 & 21 \\
\hline 5 & $\begin{array}{l}\text { Class } 123 \\
\text { mempermudah } \\
\text { pekerjaan } \\
\text { dalam } \\
\text { melakukan } \\
\text { penilaian } \\
\text { sikap }\end{array}$ & - & - & 7 & 28 \\
\hline 6 & $\begin{array}{l}\text { Class } 123 \\
\text { bermanfaat } \\
\text { bagi guru } \\
\text { dalam menilai } \\
\text { sikap }\end{array}$ & & & 6 & 29 \\
\hline
\end{tabular}

\section{Pembahasan}

A. Persepsi Peserta terhadap kemudahan Penggunaan Class123

Hasil penelitian tentang persepsi peserta diklat penilaian pembelajaran terhadap kemudahan penggunaan aplikasi Class123 adalah seperti pada grafik 1.

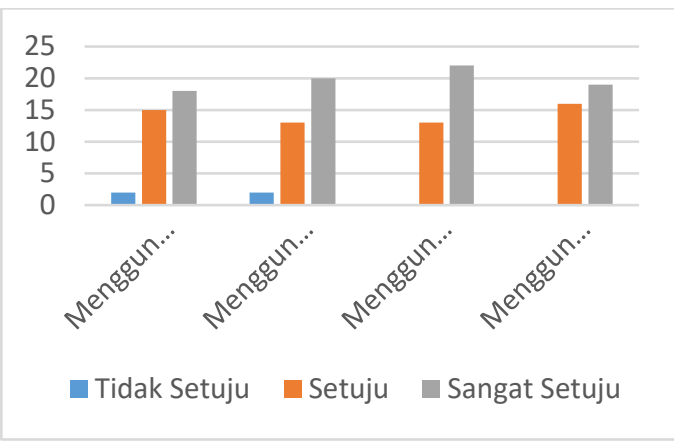

\section{Grafik 1. Kemudahan Penggunaan AplikasiClass123}

Dari distribusi jawaban responden pada aspek kemudahan penggunaan aplikasi Class123 dapat diketahui bahwa sebagaian besar responden sejumlah 22 $(62,86 \%)$ orang responden menyatakan sangat setuju bahwa menggunakan Class123 untuk penilaian sikap sangat mudah dalam penggunaanya. 20 $(57,14 \%)$ orang responden menyatakan bahwa menggunakan Class123 untuk penilaian sikap tidak terlalu banyak menyita waktu guru. Selanjutnya yang menyatakan sangat setuju dalam penggunaan Class123 untuk penilaian sikap sangat membantu dalam proses evaluasi ada $19 \quad(54,29 \%)$ orang responden. Unsur penggunaan Class123 untuk penilaian sikap sangat jelas dan mudah dipahami dinyatakan sangat setuju oleh $18 \quad(51,43 \%)$ orang responden.

Masih terdapat 2 (5,71\%) orang responden yang menyatakan tidak setuju bahwa Class123 untuk penilaian sikap sangat jelas dan mudah dipahami dan Class123 untuk penilaian sikap tidak terlalu banyak menyita waktu guru. Persepsi responden terhadap kemudahan penggunaan Class123 sebagian besar antara $\quad 18-22 \quad(51,43 \% \quad-\quad 62,86 \%)$ 
menyatakan sangat setuju, walaupun masih ada sebagian kecil yaitu 2 (5,71\%) yang meyatakan tidak setuju.

\section{c. Persepsi Peserta terhadap Manfaat Penggunaan Class123}

Hasil penelitian tentang persepsi peserta diklat penilaian pembelajaran terhadap manfaat penggunaan aplikasi Class123 adalah seperti pada grafik 2 di bawah ini:

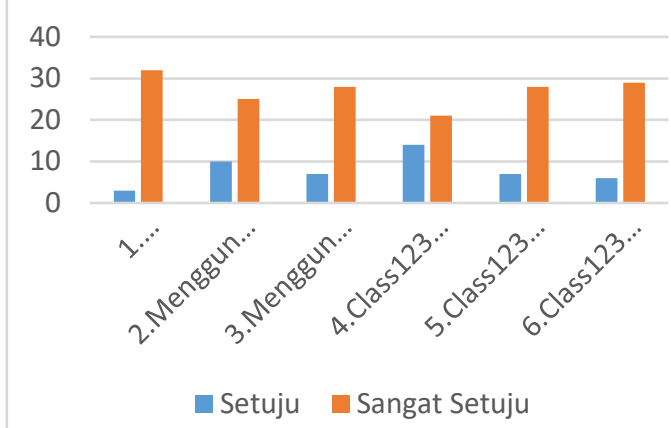

Grafik 2. Manfaat Penggunaan AplikasiClass123

Dari distribusi jawaban yang diberikan oleh responden 32 (91,43\%) orang responden menyatakan sangat setuju jika menggunakan Class123 dapat bekerja lebih cepat. 29 (82,86\%) orang responden menyatakan sangat setuju Class123 bermanfaat bagi guru dalam menilai sikap. Pernyataan tentang Class123 dapat meningkatkan kompetensi pedagogik dan Class123 dapat meningkatkan produktivitas sangat disetujui oleh 28 (80\%) orang responden. Responden yang menyatakan sangat setuju Class123 dapat meningkatkan kompetensi pedagogik sebanyak 25 responden $\quad(71,43 \%)$, sedangkan pernyataan Class123 efektif digunakan untuk penilaian sikap sangat disetujui oleh 21 (60\%) orang responden.

\section{PENUTUP}

\section{Simpulan}

Aplikasi Class123 memberikan kemudahan kepada para guru yang akan melaksanakan penilaian sikap. Hal ini terlihat dari persepsi peserta diklat terhadap kemudahan penggunaan Class123 dimana dalam rentang 51,43\% $62,86 \%$ responden menyatakan sangat setuju pada butir angket 1 yaitu menggunakan Class123 untuk penilaian sikap sangat jelas dan mudah dipahami dan butir angket ke-3, yaitu menggunakan Class123 untuk penilaian sikap sangat mudah dalam penggunaanya. Persepsi peserta diklat terhadap manfaat Aplikasi Class123 menunjukkan hasil responden menyatakan sangat setuju sebanyak $60 \%-91,43 \%$ responden pada butir angket pernyataan ke-8 yaitu Class123 efektif digunakan untuk penilaian sikap dan pernyataan ke-5 yaitu menggunakan class123 dapat bekerja lebih cepat .

\section{Saran}

Pada penelitian ini hanya mengukur persepsi peserta diklat dari unsur kemudahan dan manfaat apliasi Class123 dalam penilaian sikap. Oleh karena itu perlu dilakukan penelitian lanjutan untuk mengetahui persepsi kenyamanan pengguna aplikasi Class123. Selain itu, perlunya pendampingan kepada guruguru di madrasah masing-masing ketika menggunakan Class123 dalam menilai sikap, sehingga diharapkan hasilnya lebih maksimal.

\section{DAFTAR PUSTAKA}

Ani, Y. (2013). Penilaian Autentik dalam Kurikulum 2013. Seminar Nasional Implementasi Kurikulum. Tangerang: Universitas Pelita Harapan.

Ardi, Z. (2017). Unsuitable Majoring: Does the Reorientation Would Help the Student for Revitalize Learning Activities? https://doi.org/10.2991/icset-17.2017.69

Arifiian, Dus, F. (2015). View of Penilaian Autentik sebagai Pemandu Pembelajaran. Jurnal Pendidikan 
dan Kebudayaan Missio Retrieved March 19, 2020, from http://jurnal.unikastpaulus.ac.id/index.php/jpkm/article/view/28/17

Hidayat, R. P., \& Nugrahanti, F. (2018). Rancang Bangun Aplikasi Otomatisasi Penghitungan Penilaian Sikap Siswa Pada MTs Wisma Wisnu Madiun. Prosiding Seminar Nasional Teknologi Informasi dan Komunikasi (SENATIK). Retrieved March 19, 2020, from http://prosiding.unipma.ac.id/index.php/SENATIK/article/view/1307/1056

Kaensige, A. L., \& Yohansa, M. (2018). Penggunaan Aplikasi Class123 Sebagai Upaya Meningkatkan Keterlibatan Perilaku Siswa Kelas Xii IPA di SuatuSMA di Kota Tangerang [the Use of the Class123 Application As an Attempt To Improve Grade 12 Science Students' Behavioral Engagement in a High Schoo. JOHME: Journal of Holistic Mathematics Education, 2(1), 57. https://doi.org/10.19166/johme.v2i1.940

Kementerian Pendidikan dan Kebudayaan. (2015). Panduan Penilaian untuk Sekolah Menengah Pertama ( SMP), 32-35. Jakarta : Kementerian Pendidikan dan Kebudayaan

Muhani, Imron, A., \& Kusmintardjo. (2016). Kepemimpinan Kepala Sekolah Dasar di Daerah Terpencil (Studi Multi Kasus di SDN 2 Bakalan dan SDN 2 Kepyar Purwantoro Kabupaten Wonogiri). Jurnal Pendidikan.

Notoatmodjo, S. (2007). Teori Perilaku. Teori Perilaku. Jakarta : Rineka Cipta

Nur, A. A. (2014). Meningkatkan Kompetensi Pedagogik Guru Di SD Yayasan Mutiara Gambut. Jurnal Administrasi Pendidikan.

Permendikbud RI No. 20. (2016). Standar Kompetensi Lulusan Pendidikan Dasar dan Menengah. In Lampiran Peraturan Menteri Pendidikan dan Kebudayaan Republik Indonesia Nomor 20 Tahun 2016.

Priana, I., \& Fitriani, L. (2017). Perancangan Aplikasi Perangkat Lunak Pengelolaan Data Bank Sampah di PT. Inpower Karya Mandiri Garut. Jurnal Algoritma, 13(2), 407-413. https://doi.org/10.33364/algoritma/v.13-2.407

PRILIANTI, R. (2017). Implementasi Ujian Online Menggunakan Simudik Pada DDWK PAK Kantor Kementerian Agama Kota Pekalongan. Jurnal Informatika Upgris, 3(1). https://doi.org/10.26877/jiu.v3i1.1438

Robbins, S. P., \& Judge, T. A. (2008). Perilaku Organisasi Jilid II. Jakarta : Salemba Empat.

Salim, Y., \& Kleiner, B. H. (2001). Managing human behaviour in a publishing company: A case of the Modern English Press Jakarta. Management Research News. https://doi.org/10.1108/01409170110782658

Warsiyo. (2018). Aplikasi Sistem Penilaian Pencapaian Kompetensi Peserta Didik Untuk Guru Mata Pelajaran Dan Wali Kelas Di Mts Negeri 5 Sleman. Seri Prosiding Seminar Nasional Dinamika Informatika. Retrieved March 19, 2020, from http://prosiding.senadi.upy.ac.id/index.php/senadi/article/view/87/83 